\title{
Renewal and Rehabilitation Projects of Historic Town of Tavlusun
}

\author{
Tavlusun Tarihi Kentinde Yeniden Kullanma ve Rehabilitasyon Projeleri
}

\author{
Methiye Gül ÇöTELi
}

\section{ABSTRACT}

The heritage of historic towns is of important economic, social and cultural value. Town conservation plans and projects covering longer periods of time have a coordinative role. However, they currently hold a weak position in the revival and evolution of the historic town of Tavlusun in Kayseri, Turkey. This paper examines the case of Tavlusun as an example of this process and explores the tools and programs for preserving a small town's urban heritage. The analysis deals essentially with the current conservation projects underway in the historic town of Tavlusun and discusses the alternative urban conservation scenarios of historic heritage. The main findings of the study are that the tools of town development and preservation are not being used in a way that serves the survival of the historic areas and maintains the prestige value of the historic area. In order to secure positive future scenarios for historic towns, the first task is to make an accurate assessment of the heritage and the second is to set strategic goals by making optimal use of the amenities and the cultural identity of the place. The study found that for a sustainable environment it is necessary to relocate certain functions which are in danger of abandonment.

Keywords: Heritage conservation; local government; neighbourhood; sustainable urban renewal; urban renewal.

Tarihi şehirlerin mirası önemli ekonomik, sosyal ve kültürel bir değer taşımaktadır. Koruma planları ve daha uzun dönemleri kapsayan projelerin koordinatif bir role sahiptir. Ancak, şu anda bu plan ve projeler Kayseri'de Tavlusun tarihi yerleşmesinin canlanması ve gelişiminde zayıf bir konumda bulunmaktadır. Bu yazı, sürecin bir örneği olarak Tavlusun vakasını incelemekte ve küçük bir kasabanın kentsel mirasının korunması için kullanılan araçlar ve programlar araştırılmaktadır. Analiz esasen Tavlusun tarihi yerleşmesinde devam eden koruma projelerini ele almakta ve alternatif kentsel koruma senaryolarını tartışmaktadır. Araştırmanın temel bulguları şehir gelişimi ve korunmasının araçları tarihi alanların devamlılı̆ına hizmet eden ve tarihi alanın prestij değerini muhafaza eden bir şekilde kullanılmadığıdır. Tarihi yerleşmelerde pozitif gelecek senaryoları sağlamak amacıyla, ilk iş miras hakkında doğru bir değerlendirme yapmak ve ikincisi yaşamın hoş yölerinin ve yerin kültürel kimliğinin optimal kullanımını harekete geçiren stratejik hedefleri ayarlamaktır. Çalışma sürdürülebilir bir çevre için terk edilme tehlikesiyle karşı karşıya olan belirli işlevlerin yeniden yerleştirilmesinin gerekli olduğunu ortaya koymuştur.

Anahtar sözcükler: Miras koruma; yerel yönetim; komşuluk birimi; sürdürülebilir kentsel yenileme; kentsel yenileştirme. 


\section{Introduction}

Historic environments, cities and towns are under pressure from climate change, mass tourism, urbanization, transport, pollution, market exploitation and also from human provoked catastrophes like terrorism. Even though some of these catastrophes cannot be prevented, it has been pointed out that the historic city possesses the potential to achieve sustainability, that is, it has a sustainable urban form. ${ }^{1}$ Such elements in towns like the tangible built heritage of ancient monuments, historic buildings, traditional houses, landscapes, townscapes, the patterns of history and all the things that make a place historic, contribute fundamentally to our sense of place and cultural identity. On the other hand, the historic town maintains and uses natural resources and traditional materials. All this helps significantly to create a sustainable city and the historic town follows the sustainable urban planning principles based on the 3Rs - reduce, reuse, and recycle. ${ }^{2}$

Historical urban centres, districts, particularly inner cities, are facing the migration of inhabitants as a result of the increasingly high level of unemployment, outdated infrastructure, poor services and facilities, old housing stock. However, eonomic decline and depopulation, and the deterioration and demolition of traditional houses are not the only danger. In many historical districts, gentrification process, often leading to displacement and brutal transformation, compels the poor tenants to give up their old houses and neighbourhoods, therefore, changes the social fabric. Moreover, stagnation or even growth may cause significant damage by distorting either the tangible or the intangible environment. It should be noted that the expansion of city outskirts are also a threat to the historic urban landscape and historic town.

The last three decade, one of the main aspects of the urban problems is urban sprawl $\left.\right|^{3}$ which is assumed as having negative environmental and socio-economic impacts. The sprawl has created many problems with regard to sustainability and community. ${ }^{4}$ The term of sustainability, ${ }^{5}$ covers the environment, economics and social relationships and social justice. ${ }^{6}$ Additionally, it is related with urban growth, quality of life, health of environment, economic security and also social cohesion.

In recent years, it is acknowledged that in order to achieve the sustainable city, the densification of the urban fabric should be preferred instead of its dispersion. Since it is recognized that neighbourhoods are building blocks of our cities ${ }^{7}$ urban planners decided to seek programs for

\footnotetext{
De Moura Flores, 2002; Van Oers ve ${ }^{4}$ Duany et. al. 2000, pp. 4

Pereira Ro ders, $2012 . \quad 5$ Bruntland Report, Our common fu-

Rodwell, 2008, pp. $19 . \quad$ ture, 1987, Oxford: O.U. Press.

3 Duany, A., Plater-Zyberk, E. and ${ }^{6}$ Tweed and Sutherland, 2007.

Speck, J. 2000.
}

improving the quality of life $^{8}$ and sustainability in urban neighbourhoods. ${ }^{9}$

Some of these conditions are met in Tavlusun, a historic town in Kayseri, Turkey. Today, the district is suffering from severe social, economic and infrastructural problems. Although it is officially included as a district of the metropolitan municipality, the town has become a village, and the inhabitants are no longer city dwellers; they are in the process of transforming their identity. Town conservation plans and projects covering longer periods of time have a coordinative role. However, they currently hold a weak position in the revival and evolution of historic towns.

Consequently, this paper is a preliminary study which aims to examine the case of Tavlusun as an example of this process and to explore the tools and approaches of projects for regenerating and preserving a small town's urban heritage. The analysis deals essentially with the current conservation project underway in the historic town of Tavlusun and discusses the alternative urban renewal scenarios of historic heritage. It firstly synthesizes the common themes of heritage conservation, sustainability of heritage and sustainable neighborhood renewal. Secondly, it assesses the conservation value of Tavlusun. Then, it makes a critical review of several ongoing projects and discusses the application of this approach in the conservation of the town and concludes that a new assessment approach is required. The materials for this case study were mainly collected from three periods of fieldwork, performed from May to June 2013, from February to June 2014 and in June 2015 in Tavlusun. These include interviews with various stakeholders including the municipality and local authorities, collective and private stakeholders, villagers and migrants, and site observations, photography, mapping, and collections of documents.

\section{Cultural Heritage Conservation and Sustainable Neighbourhood Renewal}

Yet it is often precisely known that built cultural heritage can play an essential role within sustainable urban development. ${ }^{10}$ Cultural heritage is defined as the storehouse of human experience and the recognizable features of each particular place. The idea of a historical urban landscape (HUL) is a relatively new and interesting approach in the conservation literature. The HUL approach focuses on the entire human environment with all of its tangible -the city's topography, built environment, open spaces, land use patterns and spatial organization- and intangible cultural practices, not only the preservation of the physical environment. ${ }^{11}$ In this sense, the HUL approach overlapped with those of sustainable development'. And

\footnotetext{
8 Rohe and Gates 1985.

9 Choguill 2008, pp. 41-48.
} 
finally, in 2000s, we have reached to fourth era when the conceptualization of urban conservation is conceived as a holistic process of conserving the historic environment and as a component of sustainable urban regeneration. ${ }^{12}$

The importance of urban renewal process in improving the physical environment conditions and the living standards of the citizens in historical areas is widely discussed in the territory..$^{13}$ So that, the challenge between urban decay and conservation difficulties, made the urban renewal and sustainable development much more popular than before. However, all these conditions, such as rectifying the urban decay problem, meeting various socioeconomic objectives, promoting land values, changing adverse impacts on environmental quality, enhancing existing social networks, improving inclusion of vulnerable groups, which is tackled by the urban renewal process, ${ }^{14}$ are the same issues that sustainable development is concerned. Eventually, it has been recognized that urban renewal process and sustainability should be combined together, as in the form of sustainable urban renewal.

\section{Background of Urban Renewal}

Though the terms like reconstruction, redevelopment, renewal was in the fore in the 1980s and 1990s, comprehensive and strategic approaches to regeneration countering social exclusion is increased largely in $1997 .{ }^{15}$ At this time, regeneration programmes presented the physical renewal of public space, the development of commercial properties in some areas, and the provision of new and refurbished homes. Initially at least, these programmes was largely housing-led, property-led, insufficient in economic regeneration of areas and unsustainable for the local community.

Additionally, this included inadequate common spaces and design that does not allow for community. Indeed, large-scale, expensive regeneration programmes was destructive for the sense of community. ${ }^{16}$ Attempts to regenerate such neighbourhoods suffer from social polarization and disadvantages are failed. For this reason, these neighbourhood renewal strategies were likely to have an ameliorative rather than a transformative effect. According to Smith the reasons are related to "the lack of attention to the cultivation of social capital and community; the continuing provision of housing that does not meet the needs and wishes of families; and a tendency ... for 'cleansweep' schemes at the cost of restoration and reintegration. As Mark K. Smith comments as "insufficient attention has been given to restoration and reintegration". ${ }^{17}$ Rogers and Power ${ }^{18}$ expressed that "adding new and adapting old

\footnotetext{
12 Kocabaş pp.331-342.; Kocabaş 2013.

${ }^{13}$ Lee and Chan 2008.

${ }^{16}$ Power 2007, pp. 59

17 Smith, 2011.

${ }^{14}$ Couch, 1990; Adams and Hastings, 2001

${ }^{15}$ Couch, Sykes, and Boerstinghaus 2011.
}

buildings keeps neighbourhoods alive. Some demolition is inevitable, but most inner-city estates could be renovated for around half the price of building a new home, providing twice the homes on half the land."

On the other hand, since Local Agenda 21 promoted after the 1992 Rio Earth Summit, the sustainable community movement and new approaches to local community sustainability including Transition Towns, Eco-villages, Neighbourhood Renewal programmes, Zero Carbon Towns, and many others has emerged. As to UNESCO ${ }^{19}$ sustainability is characterized as: "The kind of change required by sustainability implicates each community, each household, (and) each individual. Successful solutions to problems at this level of society will need to be rooted in the cultural specificity of the town or region, if the people are to be supportive of and involved in such change". Therefore, the issue of sustainability is based on sustainable development at the local community level by not only political leaders, governments but also individuals, families, schools, hospitals, local organizations, workplaces and neighbourhoods.

Consequently, the approach to regeneration process in support of community which deals with social, economic, physical and environmental issues, collapsed..$^{20}$ Obviously, a neighbourhood might well provide the setting for the sorts of relationships and networks that is called community. ${ }^{21}$ It should be an important aspect of the renewal programs that the local inhabitants could to stay in the area. Furthermore, the local people should also be involved in the redevelopment and renewal process of the neighbourhood. For creating affordable and sustainable housing in the historic centres while preserving the architectural identity, public engagement is necessary at an early stage of redevelopment. Thus, the local community take the opportunity to participate in shaping their own future.

\section{A Concept for Sustainable Urban/Neighbourhood} Renewal

Urban renewal and urban regeneration have very similar meanings. As to Peter Roberts, ${ }^{22}$ regeneration can be defined as a comprehensive and integrated vision and action seeking to bring a lasting improvement in the economic, physical, social and environmental condition of an area that has been subject to change. According to Helen Wei Zheng, et. al. ${ }^{23}$ "urban renewal (can be) used interchangeably with urban regeneration .... aims at improving the physical, social-economic and ecological aspects of urban areas through various actions including redevelopment, rehabilitation, and heritage preservation".

\footnotetext{
${ }^{19}$ UNESCO 1997.

${ }^{20}$ House of Commons Communities ${ }^{22}$ Roberts 2000, pp.17.

and Local Government Committee ${ }^{23}$ Wei Zheng, Qiping Shen, Wang 2011.
} 
It is believed that urban renewal can significantly contribute to sustainable urban development on condition that a sustainable path is followed. Notwithstanding that most urban renewal policies are accused of driving force merely for economic regeneration and more precisely property redevelopment. ${ }^{24}$ For that reason, some researchers focused on a new evaluation of both sustainability and urban renewal. ${ }^{25}$ As a result, sustainable urban renewal grounded on social, economic and environmental aspects is emerged. Thus, sustainable urban renewal is stated as an approach addressing appropriately the two sub-systems, namely town planning including all material elements of a city and social sub-system including various stakeholders. ${ }^{26}$ In this respect, some factors affecting social sustainability of development projects, such as provision of social infrastructure, availability of job opportunities, accessibility, townscape design, heritage, security (Figure 1). ${ }^{27}$

\section{Successful Sustainable Neighbourhood Renewal Projects}

Except these projects there were so many successful stories which strike a balance between bottom-up and top-down approaches during the renewal process. This study looked at conservation in regeneration areas, based on 3 case studies in UK. Austria and Turkey.

\section{Sustainable Urban Renewal London, England}

It is suggested that urban renewal paradigm in the UK over the past 20 years, characterized by an "integrated area-based approach [involving]... public and market partners and residents". ${ }^{28}$ Therefore, the strategic elements of a regeneration project in UK which is introduced as building blocks' for regeneration. ${ }^{29}$ The objectives of sustainable renewal in UK are community development; better housing and housing management; more choice and power to tenants; tenant satisfaction; helping local political representatives or committee members. One of the most significant ideas, emerged from the UK experience, is to develop neighbourhood management initiatives, besides neighbourhood renewal fund, neighbourhood support fund, neighbourhood nursery centres, neighbourhood warden. Taylor reviewed that this model of UK has two approaches working simultaneously. First is are service led or top-down, such as area co-ordination initiatives which 'join up' services at a local level, and second, communityled or bottom-up. ${ }^{30}$

${ }^{24}$ Couch and Dennemann 2000.

${ }^{25} \mathrm{Ng} 2002$.

${ }^{26}$ Ristea, Ioan-Franc, Stegaroiu, and Croitoru 2010.

${ }^{27}$ Chan and Lee 2008.

${ }^{28}$ Musterd and Ostendorf 2008, pp.78.

${ }^{29}$ Hull 2001.

${ }^{30}$ Taylor 2000.
The building blocks are network and capacity building, improving the housing and estate management, establishing a dedicated neighbourhood team, producing a neighbourhood action plan, using the strategy to bid for funds, implementing the succession strategy, and integrate the neighbourhood with the wider community

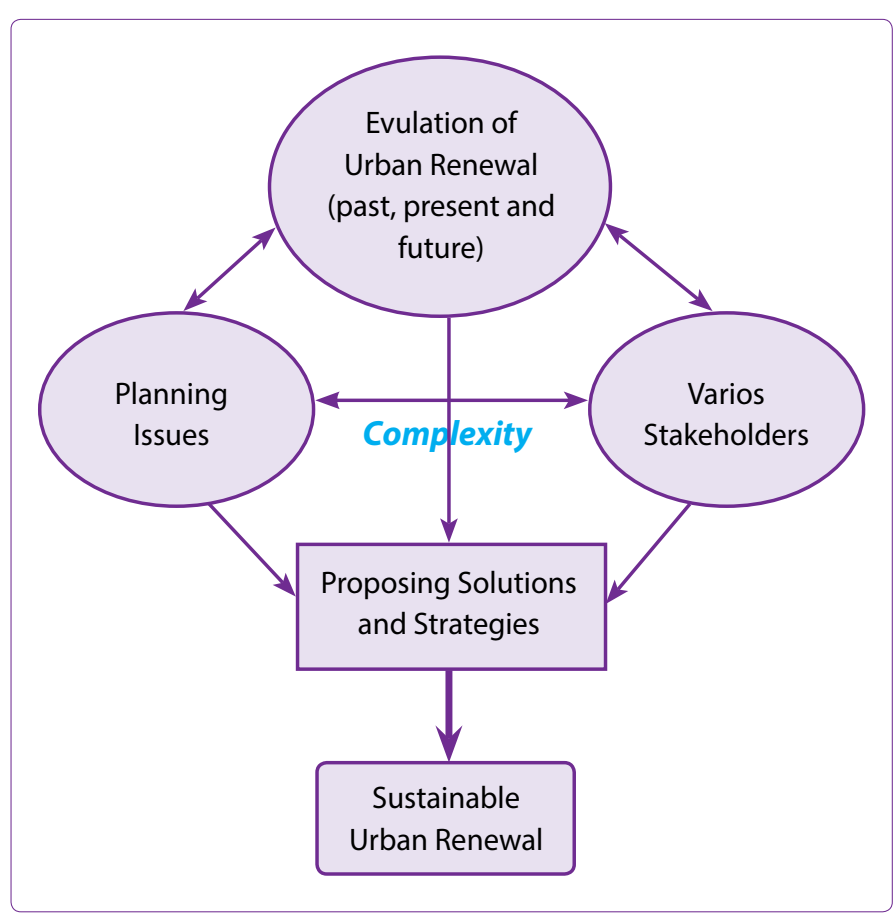

Figure 1. Path to sustainable urban renewal (Chan and Lee, 2008).

\section{Case of Southwark, Elephant and Castle}

The London borough of Southwark has become a prime site for sustainable neighbourhood renewal projects. It has the highest proportion of residents in the country who were born in Africa, thus, it has an ethnically diverse and youthful population. ${ }^{31}$ Besides, it covers areas of very diverse housing types.

There are many local factors having a large influence on Southwark's planning policies and decision making, most importantly the Community Strategy and the Local Strategic Partnership. The Southwark Alliance is the main local strategic partnership which brings together the council, other statutory organisations (for health, police, schools, and employment), with voluntary, business, faith and community sector organisations. Its role is to set the vision for the borough through the Community Strategy and to drive and monitor its implementation. ${ }^{32}$

All the members of the Southwark Alliance and its constituent organisations and partnerships are committed to the success of local area. This Southwark 2016 Plan's priorities and plans respond to local needs and concerns reducing the inequality gap.

One of the sixteen priority neighbourhoods, the Elephant and Castle is an opportunity area for combining his-

${ }^{31}$ Hill 2014.

32 "Southwark 2016 Sustainable Community Strategy", http://www.

southwark.gov.uk/downloads/ download/309/southwark_2016_ sustainable community strategy. 
toric character with a high quality design and layout of new buildings. It was planned as one of the key renewal projects aiming to transform the Elephant and Castle into an attractive town centre with top quality jobs and services. in $1998 .{ }^{33}$ Throughout the 1990s, the Single Regeneration Budget allocated funding to the Elephant and Castle for a series of small scale social and economic regeneration projects. The physical regeneration of Elephant and Castle includes the creation of a new pedestrianised town centre, market square, 5,000 new and replacement homes, up to 450,000 square feet of retail space, an integrated public transport hub, five green spaces. ${ }^{34}$

\section{Sustainable Urban Renewal Vienna, Austria}

The objectives of housing rehabilitation in Vienna, termed "Soft Urban Renewal" are priority of social criteria, avoiding social segregation or gentrification, avoiding forced change of ownership, and affordable rehabilitated housing. ${ }^{35}$ The most significant renewal strategy is "Sockelsanierung" (basic renewal), related to preserving, improving and modernizing old housing-stocks without moving tenants. "Soft" renewal strategies concentrate on smallscale and/or low-standard renewal schemes giving new hope and proud to deteriorating areas without evicting the residents. Additionally, area based renewal requires a decentralization of decision, but at the same time an interdisciplinary approach to the existing problems. ${ }^{36}$ The Partners of the projects are Vienna Land Procurement and Urban Renewal Fund (WBSF), Area Renewal Offices, and private and public landlords, owners and tenants. The Vienna Local Urban Renewal Offices (Gebietsbetreuungen Stadterneuerung - GB) which are contractors of the City of Vienna focus on sustainable urban renewal processes based on participation of the dwellers. ${ }^{37}$ It consists architecture firms and housing cooperative (Wohnbauvereinigung für privitangestellte). Wohnfonds_wien (Wiener Bodenbereitstellungsund Stadterneuerungsfonds), founded as a non-profit organisation in 1984, provide land for state-subsidised housing construction and supervise the restoration of old houses. It coordinates property developers, house owners, municipal departments and service centres of the municipality of Vienna. ${ }^{38}$ From 1984 to 2004, the fund supported the renovation of 4.335 buildings with more than 212.000 residential flats. ${ }^{39}$ And Neighbourhood Management Obere Wieden is the interface between residents, the political, administrative and economic sector and other local actors.

\footnotetext{
${ }^{33}$ Gibson and Kocabaş 2001.

34 "Opportunity Area", http://www.

cial Sustainability In Historic Districts.

elephantandcastle.org.uk/pages/ 37 "Vienna Team", https://icecprointeractive_map/113/opportunity__ ject.com/project-teams/viennaarea.html. team/.

35 "Sustainable Urban Renewal, Vi- ${ }^{38}$ www.wohnfonds.wien.at enna/Austria", http://www.wbsf. 23.06.2016.

wien.at, 23.06.2016. $\quad{ }^{39}$ Paal 2011.

${ }^{36}$ UNHABITAT, Best Practices on So-
}

\section{Lessons Learned}

Indisputably, there is no simple answer to the solutions in sustainable neighbourhood renewal, but successful initiatives have some factors in common. These are;

- to reduce the concentration of the poor in communities, and relieving their isolation;

- to integrate the community into neighbourhood regeneration processes;

- to strengthen residents' local identity through the recreation of a positive memory;

- projects may take up to 25-30 years to finish.

Conservation and Sustainable Urban Renewal in Turkey Conservation Responsibilities

In Turkey, the necessity to preserve cultural heritage in the context of urban and rural settings only started in the middle of the 20th century. However, in 2004, with the "Protection of Cultural and Natural Properties Law" no. 5226 , the PCNHL, was amended to encourage the participation of municipalities, governors as well as the related professional chambers, civil society organizations and the residents in conservation practices. In particular, it was ensured that the responsibility for the conservation of cultural heritage values via the authorization of restoration and maintenance of the listed buildings and heritage department was established within the municipality. According to the law, the "sites", "sustainability", "social and economic dimensions of protection", and "participatory site management" principles are emphasized in the process of making a conservation plan. This made a deep impact on minimizing the chaos of previous applications.

Finally, in 2005 through the "Renovation and Reuse of Deteriorated Historical and Cultural Properties" Law no. 5366, the local government's power and role were diversified and advanced. The purpose of this law is to restore and reconstruct the cultural and natural properties, sites, and regions of protected areas in accordance with the region's development strategies and to produce residential, commercial, cultural, touristic, and social amenity areas, to draw up measures against natural disaster risks, and also to renovate and reuse dilapidated historical and cultural properties. This law paved the way for the regeneration of heritage in Turkey. Nevertheless, all the improvements and appropriate measures outlined in the national documents and conservation laws still do not handle the historical urban landscape approach in a sustainable way that includes integration between the modern and old sites of the settings.

Sustainable Neighbourhood Renewal Istanbul, Turkey

Since 2003, in Turkey, neighbourhood action plans and neighbourhood renewal strategies has started to evolve. 


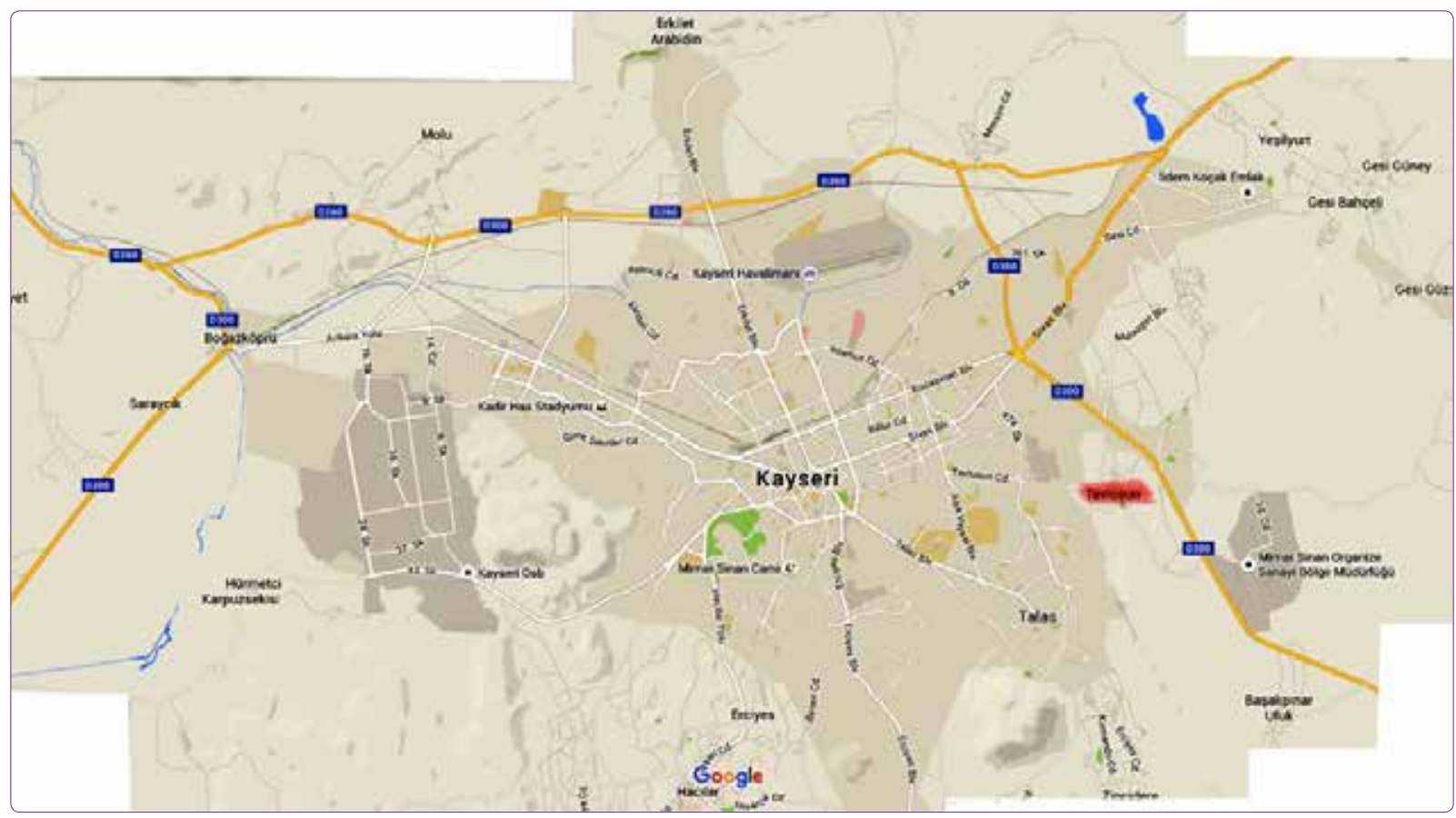

Figure 2. Location of Tavlusun (2015) and its neighbourhoods. ${ }^{42}$

The first neighbourhood action plan experiences took place in Zeytinburnu, Fatih, Beyoğlu, Küçükçekmece, Kartal and Maltepe districts, in İstanbul. Here, Fener-Balat neighbourhood in Fatih district is examined, because of their conservation oriented sustainable neighbourhood renewal strategies.

\section{Rehabilitation of Fener and Balat Districts Programme}

Rehabilitation of Fener and Balat Districts Programme was conducted jointly by the European Union and Fatih Municipality. ${ }^{40}$

The Programme's strategies are restoration of houses, social rehabilitation, renovation of the historical Balat Market and establishment of a waste management. The Programme aimed for the active participation of the district inhabitants. The objectives of the programme was to ensure sustainable renewal and the socio-economic development of neighbourhood, to produce economic activities for local residents, strengthen the technical capacity of Fatih Municipality, and create a successful and replicable model of an urban rehabilitation programme. Public participation in the programme had been given a high priority issue. Therefore, Community Participation Form, established during the program, assured not only to strengthen the local community network, but also develop an efficient and constructive cooperation between technical support team, inhabitants and the municipality. ${ }^{41}$ By this, programme generated first attempt that tackling a strategically approach for neighbourhood renewal, in Turkey.

\footnotetext{
${ }^{40}$ Altnnsay ve Ünlü, 2003.
}

\section{The Historical town of Tavlusun}

Being the capital city of ancient Cappadocia, Kayseri is one of the most attractive metropolitan cities in Central Anatolia, Turkey. Around the city, which is overlooked by the extinct volcano known as Mount Erciyes, there are several deep and narrow valleys called Derevenk, Koramaz, Gesi, Ötedere, Kelebek, Kızılırmak, Zamant etc.

\section{Location}

Tavlusun is geographically situated in the east of Kayseri and is $10 \mathrm{~km}$ from the metropolitan city center. The town, which has a panoramic view of the city of Kayseri, Mt. Erciyes and Mt. Ali, is also located in the mid-section of the Derevenk Valley which is 10 kilometres in length. Nowadays, the Tavlusun neighbourhood is surrounded by the newly constructed modern residential districts of $\mathrm{Mi}$ marsinan and Talas, and the industrial area of Mimarsinan at its south-eastern side. These residential housing areas are full of high-rise buildings, particularly apartments. The other crucially important element in relation to the town is Abdullah Gul University which is the newly established second state university in the city. These sites have made the town's location much more important than before. However, this situation has only been successful in transforming the agricultural areas into real estate investment and in renovating the high streets and avenues in and around the neighbourhood. Consequently, the good quality of roads facilitating accessibility between the residential and industrial areas has led to an increase in transit vehicle traffic

\footnotetext{
${ }^{42}$ https://www.google.com/maps/@38.7456292,35.4780835,12z.
} 


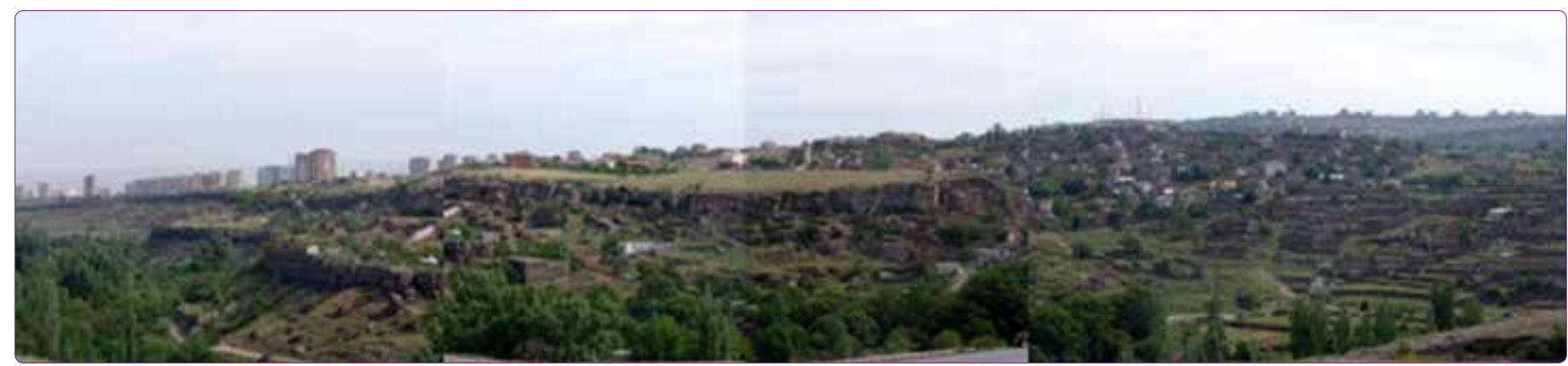

Figure 3. Panoramic view of Tavlusun.

passing through the settlement. Recently, the status of the town has changed to a neighbourhood which is part of the Melikgazi Municipality, as a result of the altered Metropolitan Law no.6360 (Figure 2).

\section{The Historical Development of Tavlusun}

The history of Tavlusun dates back at least three thousand years. As a significant settlement from the Cappadocia period to the early $20^{\text {th }}$ century, it has attracted the attention of travellers. During the $19^{\text {th }}$ century, the town was a township located in the immediate vicinity of Kayseri, which was one of the most important cities of the Ottoman Empire. It was used as a summer resort area by Ottoman bureaucrats and merchant' bourgeoisie groups from Kayseri. The price of property in Tavlusun was higher than that of other areas in Kayseri. ${ }^{43}$ This evidence indicates that Tavlusun had gained a prestigious status compared to other settlements (Figure 3).

The town in which Turks, Armenians and Greeks lived together, was formed from seven neighbourhoods (mahalle) called Yukarı (Upper), Orta (Middle), Asagı (Below), Camikebir (Mosque), Imamhüseyin, Ugurlu, and Herdem. Although the vast majority of Armenians lived in the Asagı mahalle, all the neighbourhoods had an inextricably intertwined population. Therefore there were no incidents of religious, economic or social discrimination between Muslims, Orthodox, and Gregorian inhabitants. Firstly, in 1915 , with the Armenians' and secondly in 1924, as a result of the Lausanne Peace Treaty, the Greeks' abandonment of the town and then rich Muslim Turks' migration to big cities such as Istanbul, Izmir, Ankara, the population of Tavlusun was almost depleted at the beginning of the $20^{\text {th }}$ century. ${ }^{44}$

\section{Spatial Analysis}

The historic town is a private settlement which has unique monuments, outstanding houses and paved streets from the Ottoman period reflecting a multicultural nature, qualified housing areas, and a residential pattern integrated with a green environment.

\footnotetext{
${ }^{43}$ Keskin and Cömert, 2007.
}

\section{Uses and Activities}

Because of the volcanic structure, the land is unsuitable for agricultural activities. The valley slopes and terraces were made into fruit gardens. Even though the interior valley regions are covered by dense green vegetation, the upper elevations of the valley are bare land. In the valley, there is a stream called the Derevenk which is dry in summer, but flows in winter. As a landscape which illustrates a significant stage in the human history of Tavlusun, the Herdem gardens located at the southern side of the town are another natural asset of the past. Due to its unique natural panoramic views, vistas, exceptional natural beauty and aesthetic importance, Germir-Tavlusun was listed as a natural heritage site in 1993.

The other challenge posed by the historic town is the presence of abandoned dwellings, as well as ruined buildings. Furthermore, the Asagı neighbourhood of the settlement, which consists of several monumental buildings such as ruined traditional dwellings and churches, is today completely abandoned.

The buildings are aligned only on the north-eastern slope of the Derevenk valley from the lowest part to the highest elevations of the land. The slope of the topography has a slight inclination ranging from $5 \%$ to $15 \%$. A large rocky area, which is located between the lower and upper part of the town is a significant barrier in the middle of the settlement from which the landscape of the valley can be monitored well (Figure 4).

As green fields, in the inner part of the town gardens and courtyards can be found. Thus, a balanced relationship between the occupied and empty areas of the settlement is achieved. There are no industrial or commercial areas located inside the town; all the buildings are for the use of residential and social reinforcement. On the other hand, there were also mills, which were used in the production of linseed oil in the past. However, inside the valley, there are several farms where animal husbandry is currently practiced. Tavlusun was also important for producing linseed oil which is used in illuminating, painting and cook- 


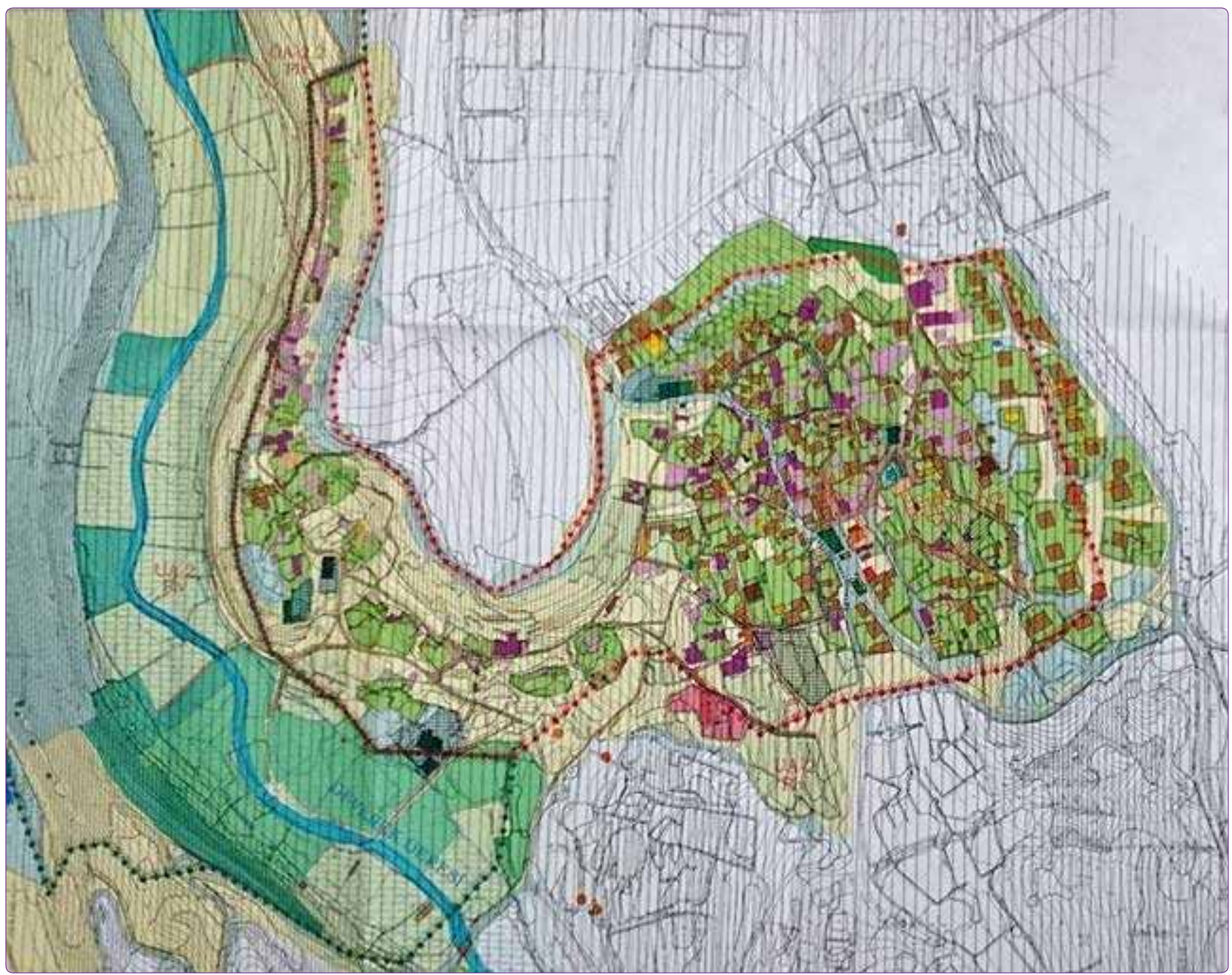

Figure 4. Land use of Tavlusun. ${ }^{45}$

ing. ${ }^{46}$ In Capadoccia, particularly in towns like Tavlusun, Gesi, and Agırnas, pigeon dung was used to obtain more products from limited agricultural land. The dovecotes, built in the higher elevations of the Derevenk Valley are important in terms of providing a secure place for pigeons to nest, and breed, and also to increase the fertility of the land and vineyards. ${ }^{47}$

Being an urban heritage site, this historic town is certainly faced with the challenge of rapid urban development. A fine view of Mt. Erciyes, Mt. Ali and the valley's landscape that can be seen in the upper elevations of the settlement is currently being marred by high-rise apartment buildings near the neighbourhood. Furthermore, the new modern concrete structures, which can be seen from inner and north-eastern part of the town, have an architectural quality which is not in keeping with the existing traditional urban fabric.

The town's roadway network is composed of winding

\footnotetext{
${ }^{45}$ Aks planlama, 2015a. $\quad{ }^{46}$ ORAN, 2014 s. $64 . \quad{ }^{47}$ Karakaya, 2014, s. 338.
}

and narrow streets. Streets which are parallel to the topography, dead ends and, rarely, stepped streets constitute the transportation network. The original street pavement can be seen on some of the streets. The two streets passing through and around the settlement are the main artery of the road system. The width of the town's street varies between $1.50 \mathrm{~m}$ to $6.00 \mathrm{~m}$. Nevertheless, a stream of heavy transit traffic flowing through the narrow streets threatens the traditional buildings. While the settlement has no water supply problems, there is no sewage or gas infrastructure in the historic town.

\section{Built Cultural Heritage}

Tavlusun retains a unique assemblage of places of cultural heritage value relating to its indigenous and its more recent inhabitants- Turks, Greeks and Armenians. Features such as landscapes, buildings, structures and gardens, orchards, natural and traditional sites, sacred places and monuments, wooden doors, oriel windows and arched bridges are treasures of distinctive value of the town in which is now part of the metropolitan area. Among the 

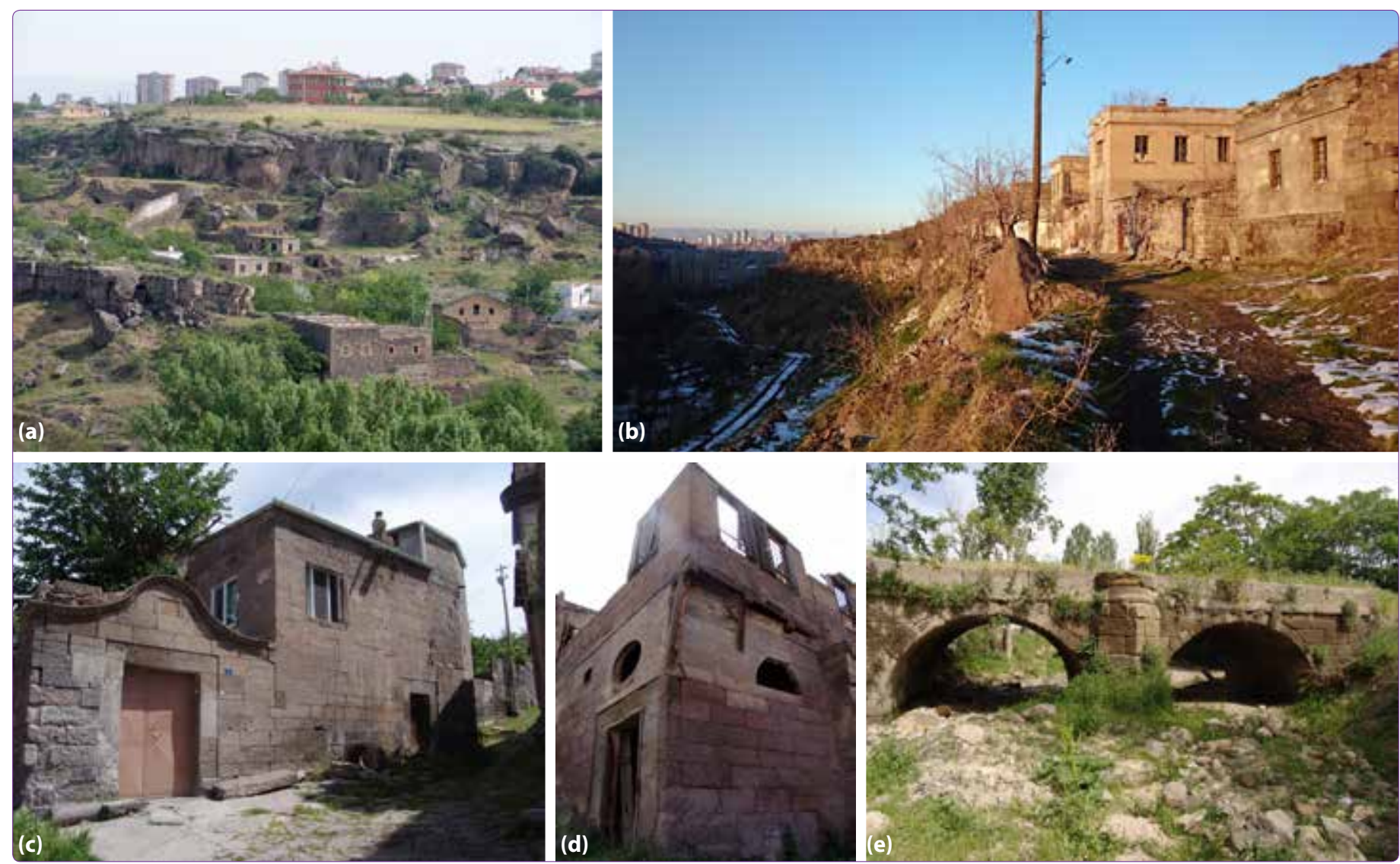

Figure 5. (a-e) Built cultural heritage of Tavlusun.

urban assets of the town, thirteen traditional dwellings, four mosques, two churches, seven fountains, two bridges and an aqueduct, Roman tomb, ruins of a monastery, dovecotes and a cemetery with monumental tombstones form a significant built heritage of the past. Although a library (along with a mosque, school and fountain) was built in 1618 within the town, it has not survived to the present day. ${ }^{48}$ This manifests the dissemination of culture and knowledge in the multicultural life of the town.

The settlement, constituting dwellings the majority of which are made of local Kayseri stone material, forms a texture that melts into the topography the of area. The buildings, generally shaped of modular cubic geometric units, constitute a natural structure. Almost all the dwellings are built on two floors and are adjacent to others. The dwellings are usually surrounded by a courtyard. Predominantly ashlar materials and, for windows and consoles, wood materials were used in the construction of buildings. However, the walls of courtyards were made of rubble stone. The covering of the buildings is flat roofing which is appropriate to the climate of the region. Although the window openings are small on the front façade, it shows a layout with repetition (Figure 5).

\footnotetext{
${ }^{48}$ Çayırdağ, 1988 , s. 271
}

According to Koç, ${ }^{49}$ towns such as Tavlusun which bear, the same environmental characteristics, have a fabric with an urban landscape character in a rural area. Even so, Koc emphasized that these towns have an accumulation of architectural heritage which can compete with the historical city of Kayseri in terms of its picturesque features. The narratives of Cömert ${ }^{50}$ about the social lifestyles and skills of playing Western musical instruments and music education among the people living in Tavlusun support this claim. Because of the lack of interest by the city administration, the town was officially declared as an urban conservation area in 1993. However, the conservation plan could not been made until 2011.

\section{Current Conservation Projects}

More recently, many responsibilities have been transferred to local authorities, namely municipalities, concerning the implementation of urban planning projects and the field of heritage conservation. The articulation among heritage conservation, the development of urban and territorial projects and local authorities' responsibilities as regards heritage are different from that of national governments'.

\footnotetext{
${ }^{49}$ Koç, 2012, s.7-8. $\quad{ }^{50}$ Cömert 2008.
} 

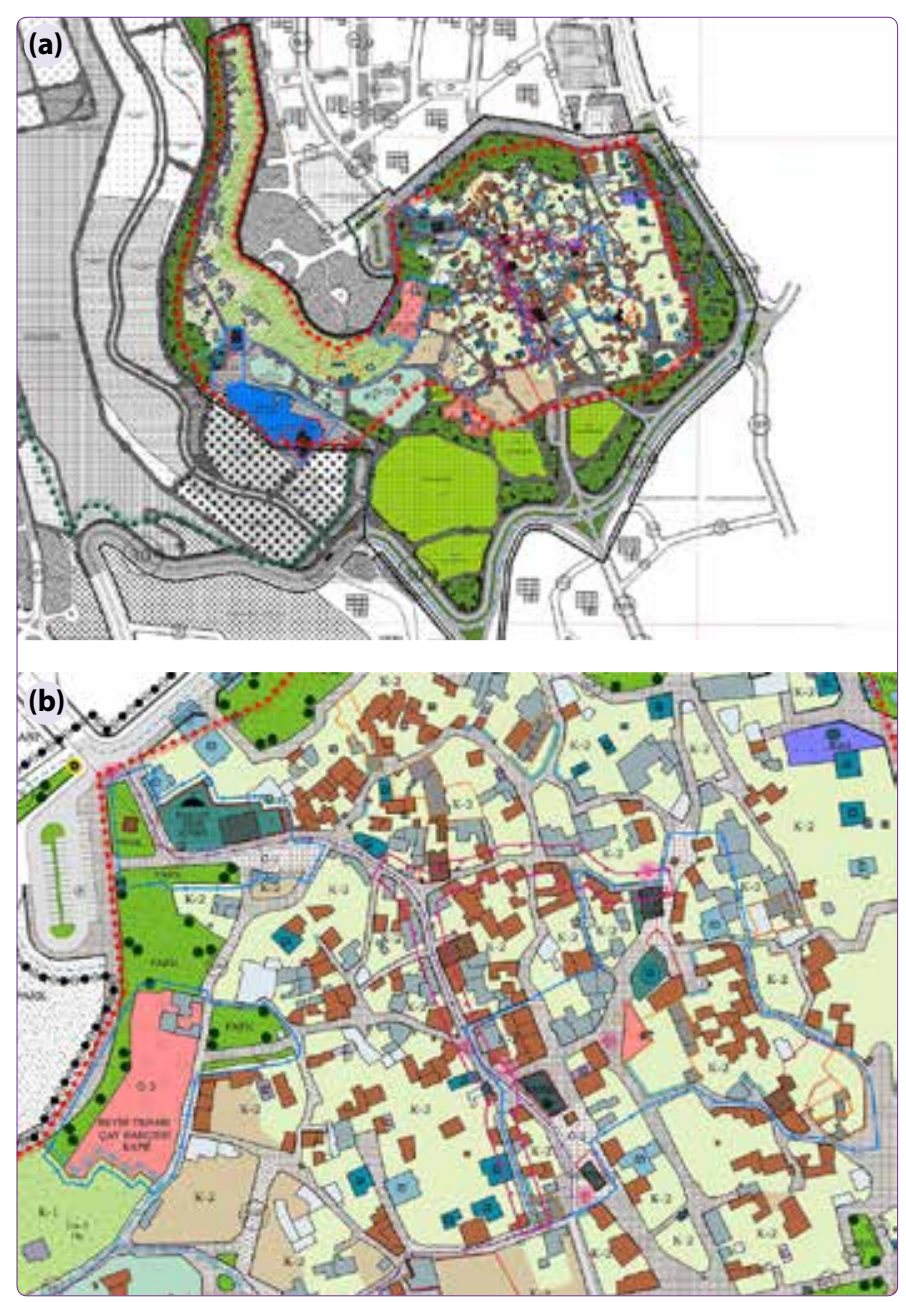

Figure 6. (a) Conservation Plan of Tavlusun; (b) A detail from the conservation plan. ${ }^{51}$

\section{Projects Conducted by Central Government}

Cultural properties to be protected in situ were taken under the legal protection of the Ministry of Culture and Tourism. The conservation plan is being implemented with the financial and technical support of the central government. A plan for the restoration and conservation of Tavlusun's built architecture and traditional dwellings started in 2011 as a collaborative effort between the municipality and the Provincial (Iller) Bank, which is an investment bank and an establishment of the Ministry of Environment and Urban Planning, developing projects for municipalities. The conservation plan of Tavlusun is under construction on behalf of the Kayseri Metropolitan municipality. The plan (Figure 6), which has not yet been approved by the Heritage Board Office of Kayseri, comprises a detailed inventory, a set of maps indicating the heritage values, and a detailed master plan indicating possible developments and priorities, rules and regulations.

\footnotetext{
${ }^{51}$ Aks planlama, 2015b; Aks planlama, 2015c.
}

Due to its built cultural heritage and natural sites, vistas and panoramic views, the Germir-Tavlusun historical route is recommended as a hiking route for tourists and sportsmen. ${ }^{52}$ However, there is no physical arrangement in the Derevenk valley related to recreation.

\section{Projects Conducted by the Municipality}

Melikgazi Municipality proclaimed 2015 as the year of the restoration of historical monuments located in the inner part of the Melikgazi district. The Mayor, Memduh Buyukkılıc, declared that "they give importance to the historical buildings in the Melikgazi district borders, because these buildings are the cultural heritage of Anatolia as well as of Kayseri. For that reason they are producing conservation plans and preserving them in accordance with the original structure. Finally they are conserving the buildings to represent the public services. These implications of the completed projects described in the Association of Historic Towns at Istanbul meeting, were shown as a successful example for other local governments by the Foundation for the Protection and Promotion of the Environment and Cultural Heritage (ÇEKÜL)".$^{53}$

The urban renovation process in Tavlusun was speeded up at the beginning of 2014 thanks to the municipality and national government. It comprises the improvement of the streets, renovation of façades and monuments such as churches and mosques, etc. At present, the municipality has embarked upon a program of full restoration of 4 monuments, 3 avenues, 3 streets and partial renovation of the façades of 94 buildings in Tavlusun. However, the design process of this program has not been completed yet. ${ }^{54}$

\section{Results and Discussion}

The Conservation Plan, and the Landscaping and Street Improvement Project for Tavlusun are said to be projects in order to maintain and conserve the urban heritage of the town. However, the town is still losing its original population due to the unemployment problem. On the other hand, the abandonment of the town has resulted in the ruin of the majority of the built cultural heritage. Management tools are useful for the management of urban conservation projects. The collaboration is an important step which was established among Melikgazi municipality, ÇEKÜL, and the Association of Historical Cities for the implementation of the projects. ${ }^{55}$ In addition, apart from the management of the projects, financing models for their implementations constitute another important step.

\section{Projects' Set Up}

It is interesting to note that the process of the conservation plan and the projects for the restoration and rehabilitation of streets are being prepared by different organiza-

${ }^{52}$ ORAN, 2014, s. 64. ${ }^{53}$ Bugün, 2015. ${ }^{54}$ Senem, 2015. $\quad{ }^{55}$ Karakose, 2015. 
tions and independently. Melikgazi municipality supports the execution of works that can be finished in the short and medium term in terms of project planning and intervenes in areas where immediate application is needed. In conservation practices and projects, a segmented approach instead of holistic one and medium and short-term investments rather than long-term ones are considered. The rationale behind the failure to define long-term goals is based on the inability to develop long-term collaborations. In addition, despite the rapid production of restoration projects, the most fundamental problem delaying their application is the extended approval process. ${ }^{56}$

Although it is not clear what the buildings will be used for after the restoration and rehabilitation projects, the first target of the projects is to preserve these traditional buildings, and at the same time the expected result is the development of tourism. Thus, this study confirms that rehabilitation policies are not reinforced by reuse policies. A possible explanation for some of our results may be the lack of appropriate "mission" for the built cultural heritage.

\section{Local Government's Role}

Local governors, who claim that Kayseri is a city of culture and tourism, intend to add historical sites for both the social and economic life of the city. Besides the newly founded Directorate of Urban Design, the municipality is currently planning to establish the Directorate of Protection Application and Supervision which will evaluate the repair and reconstruction works of immovable cultural heritage as a whole. As built cultural heritage, listed buildings have a distinct status that makes them in need of being protected and not being destroyed. Of the $1206 \mathrm{im}$ movable cultural properties located within the Kayseri city limits, 596 exist in the Melikgazi Municipality district. ${ }^{57}$ In the case of projects related to cultural and heritage matters in Tavlusun, it is particularly important to establish partnerships in the decision-making processes to achieve heritage conservation. In addition, the municipality shares the responsibility for the implementation of this conservation plan for Tavlusun. It is somewhat surprising that no participation by stakeholders, particularly the inhabitants of Tavlusun, was noted in this process. It is difficult to explain this result, but it might be related to the possibility of slowing down conservation works.

\section{Financial Sources}

The conservation of cultural heritage at local level is generally dependent on financing resources. In accordance with the Regulation on the Repair of Immovable Cultural and Natural Heritage, the Ministry of Culture and Tourism provides grants to citizens living in a historical

\footnotetext{
${ }^{56}$ Senem, 2015.
}

building for restoration works. In addition, loans for making repairs and conducting restoration works in cultural properties are given by the Mass Housing Administration (TOKI). For such loans, monthly fixed instalments are paid with an interest rate of $4 \%$ per year, and the repayment term is 10 years (KUDEB).

The Municipality deals with much extended financial means. The financial resources of the municipality are selfsufficient for the conservation works of these traditional buildings. However, a budget of 1.7 million Turkish liras, which is $15 \%$ of the total cost, was previously obtained from external sources just for these applications. A total budget of between 12 to 13 million Turkish liras was allocated for the restoration of determined buildings and monuments by the municipality. ${ }^{58}$ Financing needs are met by the Municipality of Melikgazi, the Ministry of Culture and Tourism, and ORAN Development Agency's own resources. Moreover, the Municipality is planning to lease the restored buildings for 10 years to local companies for different purposes. ${ }^{59}$ In this way, rent revenue and also the reuse of properties might be ensured. Contrary to expectations, this study finds it quite remarkable that the conservation project budget of the historical town of Tavlusun is not limited.

\section{Conclusions}

It is clear that the emergence of urban regeneration and sustainable development occurred simultaneously. At first, economic regeneration and more precisely property redevelopment, that is the main driving force regenerating the urban areas. However, later it has changed towards a more sustainable perspective. In principle, the socio-economic revitalization and conservation of a historic town or a neighbourhood depends on the awareness of its population, the existence of an economic structure, and the restoration and the reuse of its historic heritage.

The research questioned how the reuse and rehabilitation initiatives in Tavlusun affected the regeneration process and how an approach could better frame the conserving of heritage. It appears that the projects are concerned with the protection and enhancement of the physical cultural heritage of Tavlusun. The results of this study showed that the collaborative conservation network which involves the municipality, ORAN, ÇEKÜL, and the Association of Historical Cities does not contain civil society and non-governmental associations, and also universities. The reason for this is not clear but it may be due to "the idea that civil society is not ready for this process".

Tavlusun has difficulty in finding its "mission" that might run the risk of squandering its cultural heritage. In addi-

\footnotetext{
${ }^{58}$ Senem, $2015 . \quad \quad{ }^{59}$ Karakose, 2015.
} 
tion, the study found that urban renewal is left only to market and public sector in Tavlusun. Therefore, local authorities need to radically alter their approach to conservation of historic Tavlusun.

\section{Heritage and Regeneration}

The main findings of the study are that the tools of town development and preservation are not being used in a way that serves the survival of the historic areas and maintains the prestige value of the historic area. In order to secure positive future scenarios for historic towns, the first task is to make an accurate assessment of the heritage and the second is to set strategic goals by making optimal use of the amenities and the cultural identity of the place. The study found that for a sustainable historical environment, it is necessary to relocate certain functions which are in danger of abandonment.

Financial incentives in favour of the inhabitants were set up in the heritage conservation process. However, neither at the stage of preparing the preliminary investigation report nor at the stage of making the plan, was the need for public participation felt, also, the local people were not directly informed about this process in any way. However, on the other side of the coin, is the fact that the inhabitants unfortunately do not share a general sense of responsibility with the rest of humanity to safeguard the town's cultural heritage for present and future generations. Most of the native inhabitants have migrated to other districts of the metropolitan city, Kayseri, and as a result, the most of the buildings are now abandoned or dilapidated. These findings enhance our understanding of the culture-aided policy of Melikgazi Municipality instead of a culture oriented one.

\section{Recommendations}

Local governments, namely the municipalities, have a major role to play in the protection of heritage, as they work most closely with the inhabitants of heritage sites. The residents and inhabitants of heritage sites are usually the most aware of the sites' needs and are most capable of maintaining them. Therefore, when embarking on such ventures it is very important to call upon them. Unfortunately, it seems that the inhabitants, who are the key figures in the reuse and rehabilitation projects, have not been taken into account. For that reason, listed below are some recommendations related to the policies and goals of the projects:

- Communicate with the stakeholders.

- Control urban growth and give priority to the reuse of existing buildings.

- Promote employment among the inhabitants and create jobs in the areas of rehabilitation and maintenance of heritage sites.
- Reduce car traffic in the town and promote public transport, bicycles and pedestrian mobility.

- Improve the urban infrastructure facilities and public amenities in the historical environment.

- Build a roadway system without destroying interesting vestiges of the past and road covering for a better integration within an outstanding landscape.

- Plan the town's drainage system and natural gas infrastructure system.

We need more explorations on how community in Tavlusun can be revitalized in an ecologically, socially, and economically sustainable manner using the programs of sustainable neighbourhood renewal. Thus, a model that allow the improvement of old building but avoid displacement of low-income residents should be established.

\section{References}

Adams, D., and Hastings, E. M. (2001) "Urban Renewal in Hong Kong: Transition From Development Corporation to Renewal Authority", Land Use Policy, 18(3), pp. 245-258.

Aks planlama. (2015a) Land use of Tavlusun. Tavlusun Koruma Amaclı Imar Planı Arastırma Raporu. Ankara.

Altınsay, B. ve Ünlü A. E., (2003) “Fener ve Balat Semtleri Rehabilitasyon Programı", Mimar-ist, 4, s. 80-87.

Anguelovski, I., (2014) Neighborhood as Refuge: Community Reconstruction, Place Remaking, and Environmental Justice in the City, Cambridge, Massachusetts Institute of Technology.

Bruntland Report, Our Common Future, 1987, Oxford, O.U. Press.

Çayırdağ, M. (1988) “Kayseri'de Vakıf Kütüphaneleri ve Matbalı Emini Hacı Halil Efendi Kütüphanesi", Vakıflar Dergisi, Sayı 20, s. 265-288.

Chan E.H.W., and Lee, G.K.L., (2008) "Critical Factors for Improving Social Sustainability of Urban Renewal Projects", Social Indicators Research, 85, pp. 243-256.

Choguill, C.L., (2008) "Developing Sustainable Neighborhoods", Habitat International, 32, pp. 41-48.

Cömert, H. (2007) 19. Yüzyılda Tavlusun, Kayseri.

Çorağan Karakaya, N. (2014) “Kayseri'nin Gesi Beldesi, Küçük Bürüngüz(Subaşı) Köyü ile Ağırnas Vadisi'ndeki Bizans Dönemine Ait Sivil-Zirai Kaya Yapıları", Turkish Studies - International Periodical For the Languages, Literature and History of Turkish or Turkic, Sayı 9/10, s. 335-358.

Couch, C., (1990) Urban Renewal Theory and Practice, London, Macmillan Education Ltd.

Couch, C., and Dennemann, A., (2000) “Urban Regeneration and Sustainable Development in Britain - the Example of the Liverpool Ropewalks Partnership", Cities, 17(2), pp. 137-147.

Couch, C., Sykes, O. and Boerstinghaus, W. (2011) "Thirty Years of Urban Regeneration in Britain, Germany and France: the Importance of Context and Path Dependency", Progress in Planning, 75, pp. 1-52.

De Moura Flores, J. A. (2002) "The Historical City as The Sustainable Compact City Model", Proceedings of the 6th International Symposium of World Heritage Cities: Puebla, October 3-5, 2001: Prevention and protection measures for the world 
heritage cities in case of disasters, Québec: Organization of World Heritage Cities.

De Rosa, F. and Di Palma M. (2013) "Historic Urban Landscape Approach and Port Cities Regeneration: Naples Between Identity and Outlook", Sustainability, Sayı 5(10), s. 4268-4287.

Duany, A., Plater-Zyberk, E. and Speck, J. (2000) Suburban Nation: The Rise of Sprawl and the Decline of the American Dream, New York, North Point Press.

G.K.L. Lee, E.H.W. Chan, (2008) "The Analytic Hierarchy Process (AHP) Approach for Assessment of Urban Renewal Proposals, Social Indicators Research, 89(1), pp. 155-168.

Gibson, M. and Kocabas, A. (2001) "London: Sustainable Regeneration-Challenge and Response, Rendez-vous Istanbul 20011", International Urban Design Meeting, MSÜ, İstanbul, pp. 117-228.

Hull, A., (2001) “Neighbourhood Renewal: A Toolkit for Regeneration", GeoJournal, 51, pp. 306-308.

Karaköse, M. (2015) Tavlusun Kentsel Mirası Koruma Uygulamaları. Kayseri Büyükşehir Belediyesi, Melikgazi Belediyesi Başkanlığı, 10 Eylül 2015 tarihli görüşmeden.

Keskin, M. ve Cömert, H. (2007) "19. Yüzyıl Sonlarında ve 20. Yüzyıl Başlarında Türk-Ermeni illişkileri: Kayseri Örneği", Hoşgörü Toplumunda Ermeniler, C.III. I. Uluslar arası Sosyal Araştrrmalar Sempozyumu (EUSAS) Osmanlı Toplumunda Birlikte Yaşama Sanat: Türk-Ermeni iliş̧kileri Örneği, 20-22 Nisan 2006, s. 281-309.

Koç, P. (2012) “Geleneksel 'yer'[-ler-]de Zaman-Mekan Örgüsü ve Sokağın Anlamı: Derevenk-Gesi-Ağırnas Vadisi Yerleşim Örneklemi", Kayseri, Erciyes Üniversitesi Fen Bilimleri Enstitüsü Yüksek Lisans Tezi.

Kocabaş, A. (2006) Kentsel Dönüşüm (Yenileş(tir)me: İngiltere Deneyimi ve Türkiye'deki Beklentiler, İstanbul, Literatür.

Kocabaş, A. (2012) “Urban conservation in Istanbul's Historic Peninsula: progress and challenges", WIT Transactions on Ecology and The Environment, 155, The Sustainable City VII, 1, pp. 331-342.

Kocabaş, A. (2013) "The Transition to Low Carbon Urbanization in Turkey: Emerging Policies and Initial Action", Habitat International, 37, pp. 80-87.

Musterd, S. and Ostendorf, W. (2008) "Integrated Urban Renewal in the Netherlands", Urban Research and Practice, 1(1), pp. 78-92.

Ng, M. K. (2002) "Property-led Urban Renewal in Hong Kong: Any Place for the Community?", Sustainable Development, 10(3), pp. 140-146.

ORAN Regional Development Agency. (2014) Kayseri Hiking Routes and Tourism Exploration Guide, Kayseri, Kayseri Governorship Cultural Publications.

Power, A. (2007) City Survivors. Bringing up Children in Disadvantaged Neighborhoods, Bristol, The Policy Press.

Ristea, A., Ioan-Franc, V., Stegaroiu, I. and Croitoru, G., (2010) Commercial Facilities and Urban Regeneration, Amfiteatru Economic, 12(27), pp. 99-114.

Roberts, P. (2000) "The Evolution, Definition and Purpose of Urban Regeneration", Eds.: P. Roberts and H. Sykes Urban Regeneration. A Handbook, London, Sage.

Rodwell, D. (2008) Conservation and Sustainability in Historic Cities, Malden, Mass: Blackwell Publ.
Rogers, R. and Power, A. (2000) Cities for a Small Country, London, Faber and Faber.

Rohe, W.M. and Gates, L.B. (1985) Planning with Neighborhoods, Chapel Hill, NC, University of North Carolina Press.

Searfoss, L. (2011) Local Perspectives on HUD's Neighborhood Stabilization Program, Report for national community stabilization trust, University of Illinois at Urbana-Champaign.

Senem, G. (2015) Tavlusun Kentsel Mirası Koruma Uygulamaları. Kayseri Büyükşehir Belediyesi, Melikgazi Belediyesi Kentsel Tasarım Müdürlüğü, 16 Eylül 2015 tarihli görüşmeden.

Taylor, M. (2000) Top Down Meets Bottom Up: Neighbourhood Management, York, Joseph Rowntree Foundation.

Tweed, C. and Sutherland, M., (2007) "Built Cultural Heritage and Sustainable Urban Development", Landscape and Urban Planning, 83(1), pp. 62-69.

UNESCO (1997), Educating for a Sustainable Future: A Transdisciplinary Vision for Concerted Action, Report of the 19th Special Session of the General Assembly of the United Nations.

UNHABITAT, (2008) Best Practices on Social Sustainability In Historic Districts, UN-Habitat.

Van Oers, R. ve Pereira Roders, A. (2012) "Historic cities as model of sustainability", Journal of Cultural Heritage Management and Sustainable Development, Sayı 2(1), 4-14.

Wei Zheng, H., Qiping Shen, G., and Wang, H., (2014) “A Review of Recent Studies on Sustainable Urban Renewal", Habitat International, 41, pp. 272-279.

\section{Internet References}

"Location of Tavlusun". (2015). https://www.google.com/ maps/@38.7456292,35.4780835,12z [Erişim tarihi 21 Eylül 2015]

"Opportunity Area", http://www.elephantandcastle.org.uk/ pages/interactive_map/113/opportunity_area.html, [Erişim tarihi 01 Haziran 2016].

"Sustainable Urban Renewal, Vienna/Austria", http://www.wbsf. wien.at, [Erişim tarihi 23 Haziran 2016].

“Vienna Team", https://icecproject.com/project-teams/viennateam/, [Erişim tarihi 23 Haziran 2016].

Aks planlama. (2015b). "A detail from the conservation plan". Ankara: Aks planlama. http://www.aks.com.tr/projeler/korunan_alanlar_planlama_calismalari/koruma_amacli_planlar/germir_tavlusun/12.jpg [Erişim tarihi 14 Eylül 2015]

Aks planlama. (2015c). "Conservation Plan of Tavlusun". Ankara: Aks planlama. http://www.aks.com.tr/projeler/korunan_alanlar_planlama_calismalari/koruma_amacli_planlar/germir_tavlusun/11.jpg [Erişim tarihi 14 Eylül 2015]

Bugün. (2015). "Gesi mahallesi ve Koramaz vadisi UNESCO dünya mirasına aday". http://www.bugun.com.tr/son-dakika/gesimahallesi-ve-koramaz-vadisi--haberi/1728377 [Erişim tarihi 13 Eylül 2015].

Hill, D., (2014) "Regenerating Southwark: Urban Renewal Prompts Social Cleansing Fears", https://www.theguardian. com/society/2014/oct/07/southwark-Iondon-regenerationurban-renewal-social-cleansing-fears, [Erişim tarihi 13 Mayıs 2016].

House of Commons Communities and Local Government Committee (2011) Regeneration, Sixth Report of Session 201012, Volume I, London, The Stationery Office. http://www. publications.parliament.uk/pa/cm201012/cmselect/cmcom- 
loc/1014/1014.pdf, [Erişim tarihi 10 Haziran 2016].

Kayseri Büyükşehir Belediyesi. KUDEB Koruma Uygulama Ve Denetim Büroları. www.kayseri.bel.tr/web2/uploads/images/ birimler/.../kudeb_kitapcik.pdf [Erişim tarihi 13 Eylül 2015].

Milliyet. (2014). "Melikgazi Belediye Bünyesinde Kudeb Oluşturulacak". http://www.milliyet.com.tr/melikgazibelediye-bunyesinde-kudeb-kayseri-yerelhaber-512800/ [Erişim tarihi 13 Eylül 2015].

Paal, M. (2011) "The End of the Viennese Way? Changing Strategies and Spatial Impacts of Soft Urban Renewal in the Austrian Capital", Investigación \& Desarrollo, 16(1), http://rcientificas.uninorte.edu.co/index.php/investigacion/article/ viewArticle/840/4547, [Erişim tarihi 23 Haziran 2016].

Smith, M.K. (2011) "Neighborhoods and Regeneration. Theory, Practice, Issues", The Encyclopaedia of Informal Education, [www.infed.org/community/neighborhoods_and_regeneration.htm].
"Southwark 2016 Sustainable Community Strategy", http:// www.southwark.gov.uk/downloads/download/309/southwark_2016_sustainable_community_strategy, [Erişim tarihi 8 Mayıs 2016].

TBMM. (2004). “5226 sayılı Kültür ve Tabiat Varlıklarını Koruma Kanunu ile Çeşitli Kanunlarda Değişiklik Yapılması Hakkında Kanun". https://www.tbmm.gov.tr/kanunlar/k5226.html [Erişim tarihi 14 Eylül 2015].

TBMM. (2005). “5366 sayılı Yıpranan Tarihi Ve Kültürel Taşınmaz Varlıkların Yenilenerek Korunması Ve Yaşatılarak Kullanılması Hakkında Kanun". https://www.tbmm.gov.tr/kanunlar/ k5366.html [Erişim tarihi14 Eylül 2015].

UNESCO. (2011) Recommendation on the Historic Urban Landscape, Paris, France, World Heritage Centre. http://portal.unesco.org/en/ev.php-URL_ID=48857\&URL_DO=DO_ TOPIC\&URL_SECTION=201.html [Erişim tarihi 05 Eylül 2015]. www.wohnfonds.wien.at, [Erişim tarihi 5 Mayıs 2016]. 